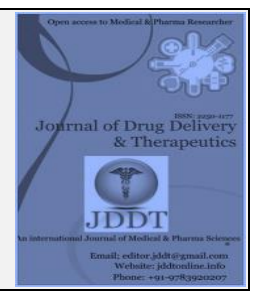

open Access

Review Article

\title{
Taryaq-i-Waba'i: A review on Potent Compound Formulation of Unani Medicine with special reference to epidemic/pandemic diseases
}

\author{
Mohd Afsahul Kalam *1, Abdul Haseeb 2, Mohd Sheeraz Mushtaq ${ }^{3}$, Zaffar Hussain ${ }^{4}$ \\ *1. Scientist Level-1, Regional Research Institute of Unani Medicine, Srinagar, India \\ 2. PG Scholar, Department of Ilmul Advia, Regional Research Institute of Unani Medicine, Srinagar, India \\ 3. Scientist Level-1, Regional Research Institute of Unani Medicine, Srinagar, India \\ 4. Professor, Department of Moalajat, Regional Research Institute of Unani Medicine, Srinagar, India
}

\begin{abstract}
Unani System of medicine is one among the oldest systems practiced all over the world. Hippocrates, father of medicine also known as father of epidemiology was the first who had written about the diseases which spread as epidemic or pandemic. After him Galen had mentioned the prevention and management of pandemic/epidemic diseases, and given several drugs for its management. A large number of Unani crude drug and compound formulations have been mentioned in the context of the prevention and management of Waba'i Amrad. Mostly all the Waba'i Amrad have pyrexia with other symptoms according to the involvement of systemic organs. One of the most important formulation is Taryaq-iWaba'i, a poly herbal pharmaceutical preparation, in the form of Pills (Huboob), and is cited by almost all the physicians of Unani Medicine viz; Jalinus, Azam Khan, Ajmal Khan, Kabiruddin etc. in their treatises. In Unani system of medicine, Amrad-i-Waba'i is described under a broad term which encompasses various contagious diseases which occurs due to impairment of environmental conditions related to air, and water. This compound formulation contains four ingredients, includes Aloe, Myrrh, Crocus and rose water. It is indicated as antidote, anti-epidemic and used for the treatment of epidemic fever, poisonous bites etc. There is no any scientific study has been done on the formulation but it is used by Unani practitioners since time immemorial. So here a brief description of the compound and its ingredients on the scientific basis is being presented for further study on the basis of Amrad-i-Waba'i.
\end{abstract}

Keywords: Taryaq-i-Waba'i, Epidemic/Pandemic, Crocus sativus, Unani Medicine.

Article Info: Received 24 April 2020; Review Completed 16 June 2020; $\quad$ Accepted 27 June 2020; Available online 15 July 2020

Cite this article as:

Kalam MA, Haseeb A, Mushtaq MS, Hussain Z, Taryaq-i-Waba'i: A review on Potent Compound Formulation of Unani Medicine with special reference to epidemic/pandemic diseases, Journal of Drug Delivery and Therapeutics. 2020; 10(4):234-237 http://dx.doi.org/10.22270/jddt.v10i4.4223

口.

Mohd Afsahul Kalam, Research Officer Unani \& Lecturer Department of Ilmul Advia, Regional Research Institute of Unani Medicine (RRIUM), Habak, Naseembagh, Campus, Hazratbal, Srinagar, 190006, India

\section{INTRODUCTION}

Unani System of medicine is one of the oldest systems which is based on the Hippocratic theory of Akhlat-i-Arb'a and Arkan-i-Arb'a. This system of medicine included a great deal of ancient Egyptian medicine as well as important components of the ancient Mesopotamian traditions. The methods of treatment according to Unani System of Medicine is divided into four different parts namely Ilaj Bi'l Ghiza (dietotherapy), Ilaj Bi't Tadbeer (regimenal therapy), Ilaj Bi'l Yad (surgery) and Ilaj Bi'l Dawa (pharmacotherapy). Considering pharmacotherapy, both single and compound drugs are being used. Among the poly-herbal drugs, various formulations such as Ma'jun, La'uq, Taryaq, Khamira, Huboob, Aqras, Shayyaf, Sharbat, Araqiyat etc. are being used from centuries with great reputation for treatment of various systemic and local ailments. Among them Taryaq are the drugs which are used for treatment of various disorders including Amrad-i-Waba'i, and other systemic disorders. Various forms of Taryaq are used like Huboob, Powder, and Ma'jun 1,2. This formulation Taryaq-i-Waba' $i$ is made in the form of Huboob 3,4. Huboob (pills) are small, round and uniformly shaped medicinal preparations, which are somewhat difference from Aqras (tablets) and Banadiq. Aqras are flat and circular in shape and Banadiq are round but bigger form of Huboob and weigh from one to three gram, but the weight of Huboob vary from one tenth of a gram to one gram ${ }^{1}$. Taryaq-i-Waba $i$, also mentioned as Taryaq-i-Afa'i by Hakim Azam Khan and Habb-i-Ta 'un by Hakim Kabiruddin 3,4,5. By almost physicians it is accepted 
that if any person has used this formulation during epidemic/pandemic spread, he will be prevented from the diseases. According to Kabiruddin its use prevents the body from epidemic diseases like Ta 'un (plague), Haida (cholera) and Jadri (small pox) etc. It is attributed to Galen of Rome who formulated the compound and said that, if a person takes during epidemic/pandemic spread he will be prevented from the disease. ${ }^{4,5}$

\section{METHOD OF PREPARATION:}

According to some of the Classical Unani Books, the preparation of Taryaq-i-Waba'i contained only 4 ingredients viz, Aloe, Mur Makki, Zafran (Crocus sativus) and Arq Gulab (Rose water). The formula for preparation of Taryaq-iWaba'i/Tiryaq-i-Afa' $i$ is given in Bayaz-i-Kabir, ALQarabadeen and Qarabadeen-i-Azam and NFUM as follows:

Two methods for the preparation of Huboob are used (i) Manual Process and (ii) Mechanical Process. 4,1,3 Taryaq-i-
Waba'i is made using Arq Gulab (rose water) as a base for dissolving Zafran (Chrocus sativus) by slow grinding. After that finely grinded powder of Mur Makki (Commiphora myrrha), and Elwa, (Aloe barbadensis), is mixed into the Mahlool of Arq Gulab and Zafran to make a Lubdi. Finally pills of gram size are being made from the lubdi. $3,4,5$

Table 1: Formula of Preparation of Taryaq-i-Wabai according to Kabiruddin (1935), [4] Anonymous (2006) 25

\begin{tabular}{|l|l|l|}
\hline S.N & Ingredients & Quantity \\
\hline 01. & Aloe vera & 10 gm (2 part) \\
\hline 02. & Commiphora myrrh & 5 gm (1part) \\
\hline 03. & Crocus sativus & 5 gm (1part) \\
\hline 04. & Arq Gulab & 100 ml (10 part) \\
\hline
\end{tabular}

Table 2: Brief description of the ingredients present in Taryaq-i-Afa'i in accordance to parts used, temperament, action their uses and pharmacological studies.

\begin{tabular}{|c|c|c|c|c|c|}
\hline S.N & $\begin{array}{l}\text { Drug } \\
\text { (Botanical } \\
\text { name) }\end{array}$ & Parts Used & Temperament & Action \& Uses & Pharmacological Studies \\
\hline 01. & Aloe vera & $\begin{array}{l}\text { Resinous } \\
\text { substance }\end{array}$ & $\begin{array}{l}\text { Hot and dry in } \\
2^{\text {nd }} \text { degree } 6\end{array}$ & $\begin{array}{l}\text { Emollient, purgative, stomachic, } \\
\text { hepatoprotective; used in } \\
\text { constipation } 6,7\end{array}$ & $\begin{array}{l}\text { Antioxidant, }{ }^{8} \text {, Antiviral, }{ }^{9} \text { Anti- } \\
\text { Inflammatory } 10 \text {, } \\
\text { Immunomodulatory, Analgesic } \\
11 \text {, Antiaging } 12\end{array}$ \\
\hline 02. & $\begin{array}{l}\text { Commiphora } \\
\text { myrrh }\end{array}$ & $\begin{array}{l}\text { Oleo-gum- } \\
\text { resin }\end{array}$ & $\begin{array}{l}\text { Hot and dry in } \\
2^{\text {nd }} \text { degree } 6\end{array}$ & $\begin{array}{l}\text { Antiseptic, siccative, detergent, } \\
\text { carminative, stomachic, } \\
\text { expectorant, anti-inflammatory, } \\
\text { deobstruent; used in } \\
\text { epidemic/pandemic spread, } \\
\text { constipation, cough, asthma, } \\
\text { dryness of throat, hoarseness of } \\
\text { voice } 6,7\end{array}$ & $\begin{array}{l}\text { Antioxidant, anti-bacterial } 13 \\
\text { anti-inflammatory } 14 \text {, analgesic } \\
15 \text {, neuroprotective } 16 \text {, antiviral, } \\
\text { Hepatoprotective } 17\end{array}$ \\
\hline 03. & Crocus sativus & Stigma & $\begin{array}{l}\text { Hot in } 2^{\text {nd }} \text { and } \\
\text { dry in } 1^{\text {st }} \\
\text { degree }{ }^{6}\end{array}$ & $\begin{array}{l}\text { Anti-inflammatory, detergent, } \\
\text { cardio-tonic, liver tonic, } \\
\text { diuretic; used in hepatitis, } \\
\text { metritis, cardiac weakness } 6,7\end{array}$ & $\begin{array}{l}\text { Anti-Aging } 18 \text {, antioxidant }{ }^{19}, \\
\text { antidiabetic, dyslipidemic } 20, \\
\text { Anti-inflammatory, analgesic } 21 \\
\text { Antidepressant } 22,23\end{array}$ \\
\hline 04. & Arq Gulab & Rose water & $\begin{array}{l}\text { Murakkabul } \\
\text { Quwa, near to } \\
\text { cold } 7\end{array}$ & $\begin{array}{l}\text { Anti-inflammatory, analgesic, } \\
\text { cardiotonic, brain tonic, } \\
\text { exhilarant; useful in palpitation, } \\
\text { syncope } 6,7\end{array}$ & $\begin{array}{l}\text { Antioxidant (in vitro), Hypnotic } \\
24\end{array}$ \\
\hline
\end{tabular}

Dosage and Method of administration: 1-2 pills are recommended. During pandemic for prevention purpose, 2 pills at morning or bed time is indicated along with Arq-iBadiyan $120 \mathrm{ml}$ or Arq-i-Gulab $50 \mathrm{ml}$, for 2-3 days in every week, but should be avoided, when a person become affected from pandemic. ${ }^{4}$ Sometimes it is taken in quantity of $2 \frac{1 / 4}{\mathrm{gm}}$ with vine or any other similar liquid, it prevents form diseases during epidemic/pandemic spread. ${ }^{5}$

Action and Uses: It is indicated for Dafi' Samoom (antidote), Dafi' Athrat-i-Waba (antiepidemic) and used for the treatment of Humma-i-Waba'i (epidemic fever), Ta 'un (plague), Laza-i-Hashrat (insect bite). 3,4,5,25

\section{DISCUSSION:}

Elwa (Aloe barbadensis): It is an important drug of Unani Medicine, which is obtained from the dried juice of Aloe vera leaves pulp. It is also known as Sibr. It is hot and dry in $2^{\text {nd }}$ degree. 7 It has Mushil (purgative), Muhallil-e-warm (resolvent), Muharrik-e-Kabid (liver stimulant), Mulayyin (emollient), Mushil (purgative), Muqawwi-i-Mi'da (stomachic), Muqawwi-i-Jigar (hepatoprotective) effects etc. $6,7,26$.

Mur Makki (Commiphora myrrha): It is an oleo-gum-resin obtained from a large and beautiful plant Commiphora myrrha Engl. of family Burseraceae. It is commonly known as Mur Makki in Unani System of Medicine. The drug is hot and dry in $2^{\text {nd }}$ degree and recognized to possess significant Muhallil (anti-inflammatory), Mundij (concoctive), Dafi' ta 'ffun (antiseptic), Mulayyin (laxative), antitumor and antidote properties. 6,7,26. The gum contains polysaccharides and low proteins and tannin and high calcium, while the volatile oil is composed of steroids, sterols and terpenes 27 . Flavonoids, alkaloids, tannins, glycosides, steroids, saponins, tannins and 
terpenoids were identified in Methnolic extract. Various studies such as antioxidant, anti-bacterial, 13 antiinflammatory, 14 analgesic 15 , neuroprotective ${ }^{16}$, antiviral, hipatoprotective 17,28 activities can make it useful for pandemic/epidemic spread.

Zafaran (Crocus sativus): Dried stigmas and styles are used for its muhallil (anti-inflammatory), mundij (concoctive), qābid (astringent), mugarri (adhesive) and mufattih (deobstruent) properties so used as mufarreh qalb (exhilarant), muqawwi-i-qalb (cardiotonic), muqawwi-idimāgh (brain tonic), muqawwi-i-'așāb (nervine tonic), muqawwi-i-jigar (liver tonic), muqawwi-i-bașr (eye tonic), muqawwi-i-mi'da (stomach tonic), muqawwi-i-gurda (renal tonic), muharrik-i-bāh (sexual stimulant), mudirr-i-bawl (diuretic), musakkin (sedative), dāf-i-tashannuj (antispasmodic), munaffith-i-balgham (expectorant), mu'rriq (diaphoretic), mudirr-i-hayd (emmenagogue) properties. 6,7,26 On the basis of these properties, Zafran used for the treatment of Shaqiqa (migraine), Warm Tajawif-i-Anaf Muzmin (chronic sinusitis), Ihtibās-i-Bawl (urinary obstruction), Sozish-i-Bawl (inflammation of the urinary tract), Mālankholiā (melancholia), depression, Sadma (shock), menstrual disorders, Su'al yābis (dry cough), Shahìqa (whooping cough), Warm Sho'ba al-riya (bronchitis) etc. It is added in Surma (collyrium) and applied in eyes to induce shining and to cure Khafash (snow blindness), Zarqa (blue discoloration of eye) and day blindness 29,30 . It also glows the body complexion ${ }^{29}$.

Arq-i-Gulab (rose water): Arqiyat are liquid preparations, obtained by the distillation of fresh aromatic flowers, fruit juice, seeds or or crude drugs in aqueous medium ${ }^{4}$. Different types of Arqiyat like Arq Gulab, Arq Kewra, Arq mundi, Araq Badiyan, Arq Kasni etc., have been used either alone or as an ingredient in different compound formulations by the traditional practitioners for the treatment of disorders related to various organs. 1,4 Arq Gulab is a clear, nonviscous, liquid preparation obtained by the aqueous distillation of dully macerated Rosa damascena flowers. ${ }^{4}$ It is described to be Mubarrid (refrigerant), Muhallil (antiinflammatory), Musakkin (analgesic), Dafi'Atash (reduces thirst), Naf-i-Ashob-i-Chashm (gives relief in conjunctivitis), Mufarrih (exhilarant), cardio-tonic, properties and used for the management of anxiety, syncope, palpitation and provides strength and cheerfulness to heart. 4 It is mainly prescribed when there is a weakness of the principal organs of the body like Brain, Heart and Liver. According to study done by Golla et al. 2011 Arq Gulab was found to possess significant hypnotic activity in albino rat and in vitro antioxidant activity 24

\section{CONCLUSION}

In the light of above discussion the inference may be drawn that the Taryaq-i-Waba' $i$ is one of the best Unani formulation with a lot of health benefits. It has been mentioned by renowned Unani physicians for prevention and management of epidemic and pandemic diseases under the name of Amrad-i-Wabai. Various functions of Taryaq-i-Wabai is attributed to its various ingredients which possess antioxidant, antiviral, immunomodulatory, antiinflammatory, tonic for nerves, brain, heart and liver, laxative, expectorant, demulcent, antipyretic, antitussive etc. properties. There is no scientific study on Taryaq-i-Waba' $i$ has been done till date, but on the basis of scientific studies of its ingredients, it can be said that the compound has ability of prevention and management of such type of epidemic/pandemic diseases. So it is need of the time that, scientific studies and clinical trials should be done on this compound formulation to ensure its scientific validation for clinical use in patients in general during pandemic spread.

\section{REFERENCES:}

1. Anonymous. National Formulary of Unani Medicine, Part VI. New Delhi: Central Council for Research in Unani Medicine; 2011. P. 13,187 .

2. Anonymous. National Formulary of Unani Medicine, Part III. New Delhi: Central Council for Research in Unani Medicine; 2001; 96-98.

3. Khan Azam. Qarabadeen Azam (Persian) Dilli Printing Works; 1338 Hijri.

4. Kabiruddin M. Bayaz-i-Kabir. Vol-2. New Delhi: Aijaz Publishing House; 1935. pp 12, 37, 95-105.

5. Kabiruddin M. Al-Qarabadin. $2^{\text {nd }}$ edn. New Delhi: Central Council for Research in Unani Medicine. 2006. P. 57

6. Kabiruddin M. Makhzanul Mufridat. New Delhi: Idara Kitab ul Shifa, 2014. P. 89, 90,380,381,239,240.

7. Ghani Najmul. Khazainul Advia. New Delhi: Idara Kitab ul Shifa; 2011. P. 308,309,761-763,1052, 1133, 1135, 1136, 1229,1230

8. Rajasekaran S, Sivagnanam K, Ravi K and Subramanian S, "Antioxidant effect of Aloe vera gel extract in streptozotocininduced diabetes in rats" Pharmacol Rep, 2005; 57:90-96.

9. Kim HS, and Lee BM, "Inhibition of Benzopyrene-DNA adduct formation by Aloe barbadensis Miller." Carcinogenesis, 1997; 18:771-76. http:// dx.doi.org/10.1093/carcin/18.4.771

10. Hutter JA, Salmon M, Stavinoha WB, Satsangi N, Williams RF, Streeper RT, "Anti-Inflammatory C-Glucosyl Chromone from Aloe Barbadensis" J Nat Prod, 1996; 59:541-3. http://dx.doi.org/ 10.1021/np9601519 PMid: 8778246

11. Bitz Smith, and Gerard, "Aloe vera gel in peptic ulcer therapy: preliminary report" Journal of the American Osteopathic Association, 1963; 62:731- 35. PMid: 13971654

12. West DP, and Zhu YF, "Evaluation of Aloe vera gel gloves in the treatment of dry skin associated with occupational exposure" Am J Infect Control, 2003; 31:40-2.

13. Shaikh J, Vishakha K and Ramyasree D, "Evaluation of antibacterial activity of Commiphora myrrha against antibiotic resistant clinical pathogens" Indian Journal of Pharmaceutical and Biological Research, 2015; 3(3):7-11.

14. Singh RK, Joshi VK and Gambhir SS, "Anti-Inflammatory Activity of Some Traditional Medicinal Plants" Ancient Science of Life, 1998; 18(2):160-164.

15. Su S, Wang T, Duan J A, Zhou W, Hua Y Q, Tang Y P, et al, "Antiinflammatory and analgesic activity of different extracts of Commiphoramyrrha" LEthnopharmacol, 2011; 134(2):251-258.

16. Alizadeh R, Abedi G, Ashrafi J and Mansoori K, "Effect of Commiphora myrrha on Sciatic Nerve Regeneration" International Journal of Biology and Allied Science,2014; 3(9):2108-2118.

17. Ahmad A, Rais M, Ganaie MA, Rizwan S R, Mohsin K, Al-Jinoobi FI et al. "Hepatoprotective effect of Commiphora myrrha against dGalN/LPS-induced hepatic injury in a rat model through attenuation of pro inflammatory cytokines and related genes" Pharm Biol, 2015; 53(12):1759-1767.

18. Xing, HG, Li, Z, Huachen, W, Hong, DC, "Efficacy and safety of innovative cosmeceuticals". Clin. Dermatol, 2008; 26:367-374.

19. Hosseinzadeh, H, Molaei, M, Shakeri, M, Rajabi, O, Shamsa, A, "Evaluation of Crocus sativus L. (saffron) on male erectile dysfunction: A pilot study" Phytomedicine 2009; 16:690-693.

20. Eghdami, K, Erfanparast, A, Farshid, AA, Samadi, F, Tamaddonfard, E, "Comparison of the effects of crocin, safranal and diclofenac on local inflammation and inflammatory pain responses induced by carrageenan in rats" Pharmacol. Rep, 2013; 65:1272-1280. 
21. Tamaddonfard, E, Erfanparast, A, Farshid, AA, Imani, M, Mirzakhani, N, Salighedar, R, Tamaddonfard, S, "Safranal, a constituent of saffron, exerts gastro-protective effects against indomethacininduced gastric ulcer" Life Sci. 2019, 224:88-94.

22. Murray, CJ and Lopez, AD. "Alternative projections of mortality and disability by cause 1990-2020: Global burden of disease study" Lancet, 1997; 24:1498-1504. 45.

23. Khazdair, MR, Anaeigoudari, A, Hashemzehi, M, Mohebbati, R, "Neuroprotective potency of some spice herbs, a literature review" J. Tradit. Complement. Med, 2018; 9:98-105.

24. Golla Upendarrao, Ashok Kumar, K, Solomon Suder Raj, B, "Assessment of antioxidant and hypnotic activity of Unani formulation Arq Gulab" Pharmacologyonline, 2011; 1:930-941

25. Anonymous. National Formulary of Unani Medicine, Part I. New Delhi: Central Council for Research in Unani Medicine; 2006. P. 154 .
26. Hakim Mohd Abdul. Bustanul Mufridat. New Delhi: Idara Kitab ul Shifa; 2011

27. Yaser AJ, Muneer A, Abdelhafid B, Daoudi CS and Hammadi AL, "Chemical and Phyto chemical Analysis of Some Antidiabetic Plants in Yemen,International Research Journal of Pharmacy, 2013; 4(9):72-76.

28. Mohamed AA, Ali SI, EL-Baz FK, Hegazy AK and Kord MA. "Chemical composition of essential oil and in vitro antioxidant and antimicrobial activities of crude extracts of Commiphora myrrha resin" Industrial Crops and Products, 2014; 57:10-16.

29. Ibn Hubal Baghdadi. Kitab al-Mukhtarat fi'l Tibb, Vol.2. New Delhi: Central Council for Research in Unani Medicine, Ministry of AYUSH, Govt. of India; 2005. P. 133

30. Ibn Sina. Al-Qanun fi'l-Tibb. Vol 2. (English translation by Department of Islamic Studies Jamia Hamdard), New Delhi: Hamdard University; 1998: 